\title{
Preliminary palynostratigraphy of the Permian - Lower Triassic sediments in Jameson Land and Scoresby Land, East Greenland
}

\author{
STEFAN PIASECKI
}

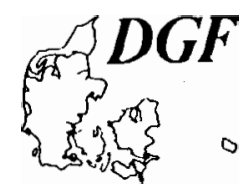

\begin{abstract}
Piasecki, S.: Preliminary palynostratigraphy of the Permian-Lower Triassic sediments in Jameson Land and Scoresby Land, East Greenland. Bull. geol. Soc. Denmark, vol 32, pp. 139-144. Copenhagen, September, 4th, 1984. https://doi.org/10.37570/bgsd-1983-32-10

The presumed Carboniferous, Permian and Lower Triassic sediments of Jameson Land and Scoresby Land, have been palynologically investigated. Four main assemblages are recognised which form the basis for a coarse stratigraphy. The Lower Permian Potonieisporites assemblage occurs in all palynologically productive fine-grained sediments from the Gurreholm Dal and the Mesters Vig Formations. The lowermost part of these sediments in Skeldal may be of latest Carboniferous age. An Upper Permian Vittatina assemblage characterises the lower part of the Foldvik Creek Formation. An Upper Permian I Lower Triassic Protohaploxypinus assemblage occurs in the upper part of the Foldvik Creek Formation. The Lower Triassic Wordie Creek Formation contains a Taeniaesporites assemblage.

The preliminary investigation suggests a gradual change in the palynoflora. This again points to presence of a complete or almost complete sedimentary transitional sequence from the UpperPermian to the Lower Triassic.
\end{abstract}

Stefan Piasecki, The Geological Survey of Greenland, Øster Voldgade 10, DK-1350 Copenhagen K, Denmark, November 10th, 1983.

\section{Introduction}

A basinal analysis project in connection with hydrocarbon evaluation of Permian - Lower Triassic sediments in Jameson Land and Scoresby Land was undertaken by the Geological Survey of Greenland in the summers of 1982 and 1983. To provide the stratigraphical basis for this study, a large number of fine-grained sediment samples were collected for palynological studies. Many of these samples have been processed and examined. The preliminary results show a biostratigraphical pattern that is similar to the biostratigraphy in equivalent sediments at Kap Stosch in the northern part of the basin (Balme 1979). The improved dating of the Permian sequence suggests that further work on the pollen and spores will provide a very useful stratigraphical tool.

The stratigraphy of the late Palaeozoic - early Mesozoic sediments of Jameson Land and Scoresby land in central East Greenland has been based on inadequate palaeontological material. Thus the biostratigraphical correlations have been loose. The Lower Permian sediments were primarily dated by scattered, fragmentary and badly preserved macro plant fossils (Bierther 1941, Witzig 1951, 1954, Halle 1953, Bütler 1961). Vertebrates have also provided a basis for age determination (Jensen 1975; Bendix-Almgren 1976), but these have also been strongly dependent on plant fossil evidence.

One palynological age determination by $\mathrm{N}$. Hughes (in Kempter 1961) of one bed at the base of the Ødemarksdal Member in the type section has been used for long distance correlation of lithologically different units (Perch-Nielsen et al. 1972). Unfortunately, sampling of all the finegrained beds in the same section in 1983 provided no palynomorphs at all.

The Upper Permian sediments are dated by conodonts, brachiopods and the ammonite Cyclolobus kullingi. This composite evidence suggests a Late Permian age (see Perch-Nielsen et al. 1972). In contrast the Lower Triassic sediments are well dated by ammonites and a biozonation has been erected (Grasmück \& Trümpy 1969).

The lithostratigraphy of the Permian - Lower Triassic sediments is poorly defined. Lower Per- 

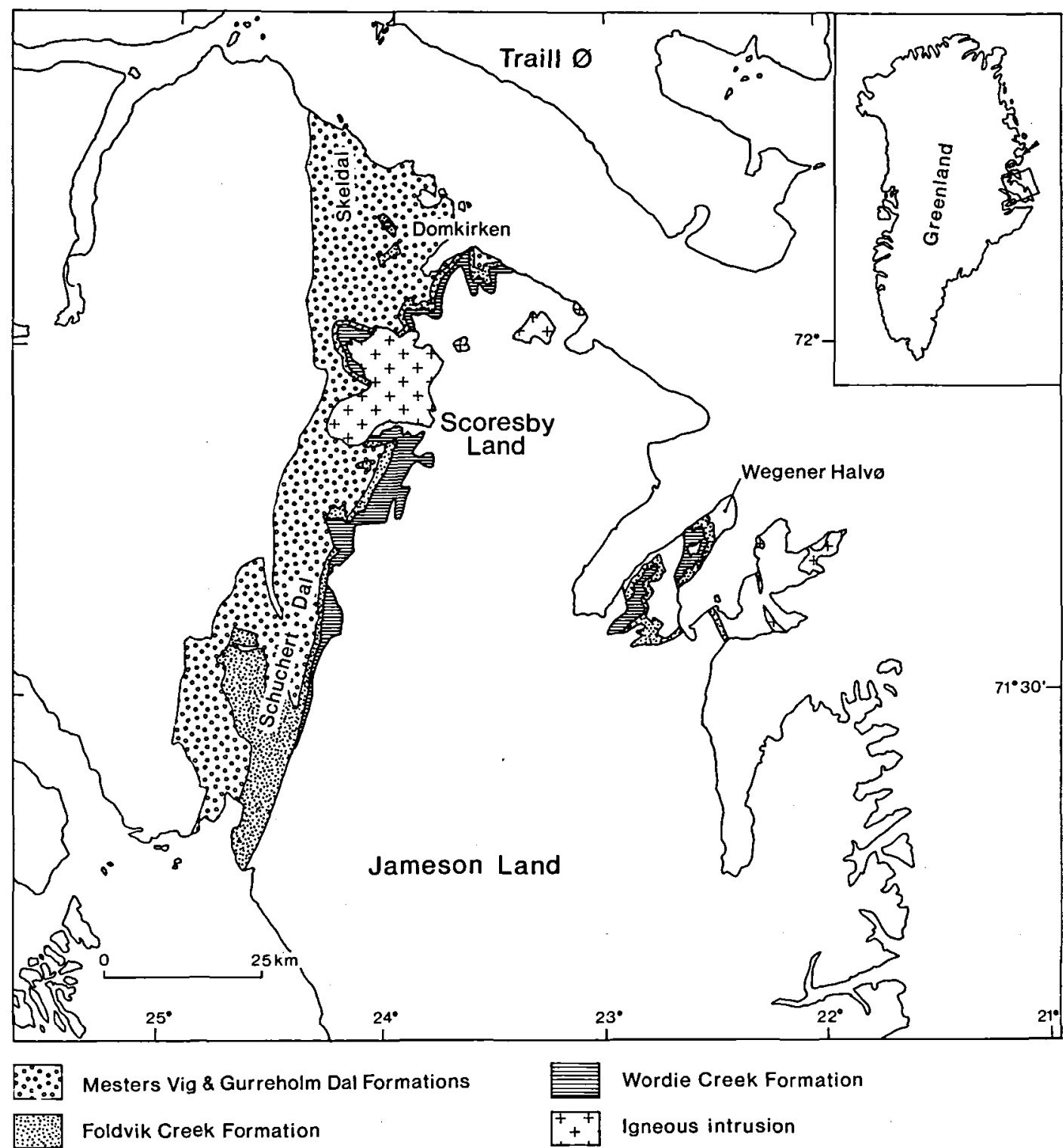

Fig. 1. The distribution of outcropping Permian and Lower Triassic sediments in Jameson Land and Scoresby Land, East Greenland. Kap Stosch is marked with an arrow on the small map of Greenland.

mian sediments occur in Jameson Land and Scoresby Land and the outcrop areas are separated by igneous intrusions (fig. 1), so that direct correlations is not yet possible. Therefore, separate lithostratigraphical schemes have traditionally been erected for each region.

The Lower Permian sediments of the northern region, Scoresby Land, are composed mostly of cyclic fluviatile units. A number of lithostratigraphical units have been designated for this se- quence (Bierther 1941, Witzig 1954, PerchNielsen et al. 1972). The Mesters Vig Formation, including five members (fig. 2), was originally designated for the whole Jameson Land - Scoresby Land region (Perch-Nielsen et al. 1972). However, it is now apparent that these members cannot be used consistently throughout the whole region. For example, in the southern region only the Snekuppel Member, Gurreholm Dal Formation, is sedimentological comparable to the sedi- 


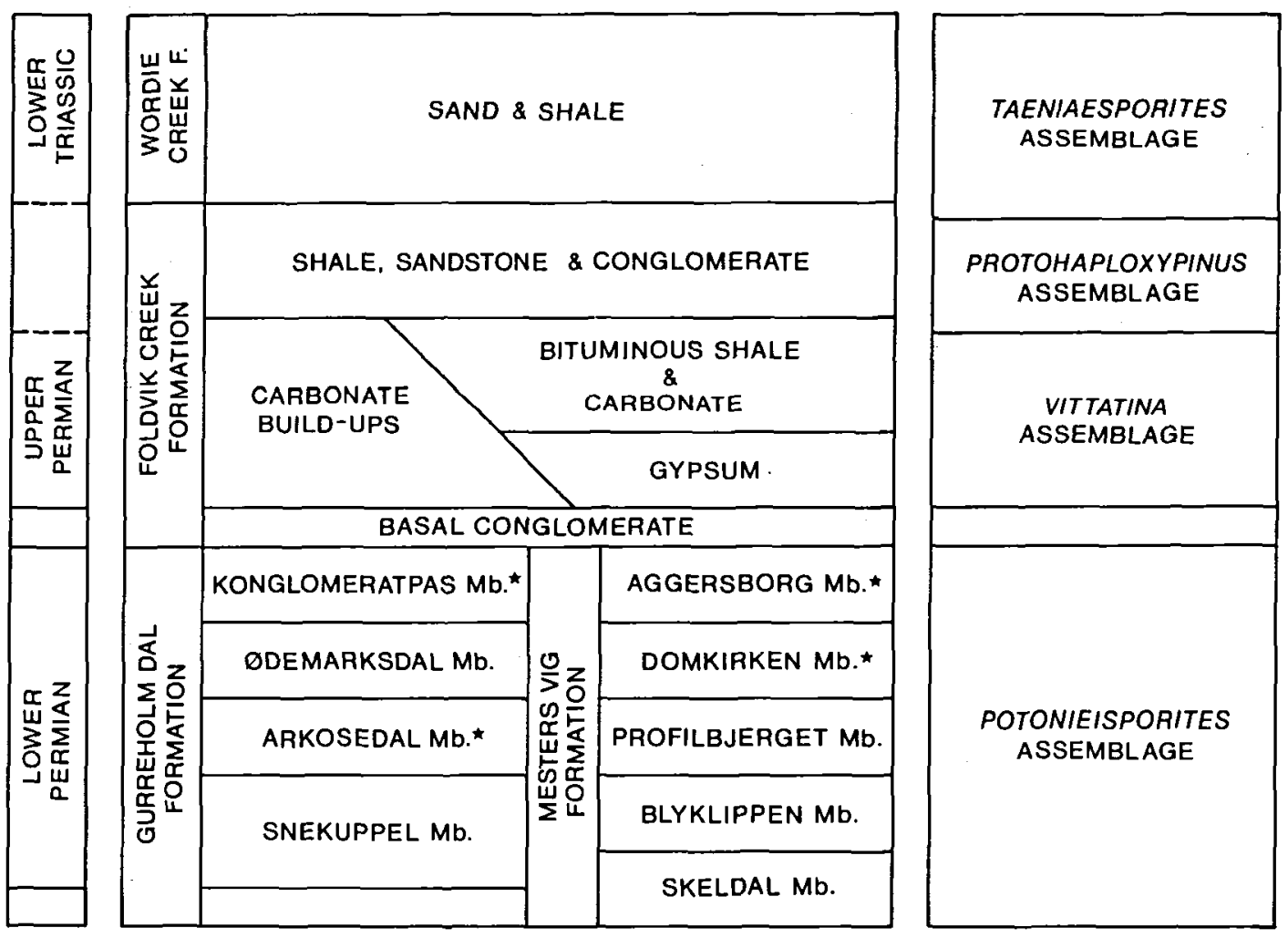

Fig. 2. Stratigraphical scheme of the Permian-Lower Triassic sediments. The members marked with a star have not provided any palynomorphs.

ments in the northern region. Thus, for the purpose of this article the Mesters Vig Formation is only used in the northern region.

Kempter (1961) defined the Gurreholm Dal Formation, comprising four members (fig. 2), for the Lower Permian sediments of the Schuchert Dal region. The formation represents deposition in a system of alluvial fans (Konglomeratpas, $\emptyset$ demarksdal and Arkosedal Members) fringing the westernly crystalline basement. These fans were located along a fault and they passed eastwards into a fluviatile system (Snekuppel Member) (Collinson 1972).

The Bjørnbos Corner Formation (Kempter 1961) has been regarded as older than the Gurreholm Dal Formation. The lithology of the Bjørnbos Corner Formation is closely comparable to the lowermost conglomeratic part of the Snekuppel Member, Gurreholm Dal Formation, and thus the formation is included in this member.

The Foldvik Creek Formation (Koch 1929) is composed of a number of interfingering lithologies including a basal conglomerate, followed by evaporites, carbonate build-ups, bedded carbonates and bituminous shales and finally a sequence of shale, sandstone and conglomerate (fig. 2). The lower part of the Wordie Creek Formation (Koch 1929) is mainly alternating thin beds of silt and fine-grained sandstone.

\section{Composition and occurrence of pollen and spore assemblages}

More than 400 samples of Permian-Lower Triassic sediments have been processed and analysed for pollen and spores. They contain associations of very different composition which can be assigned to four groups / assemblages. The lower assemblage is significantly different from the other three and is separated from them by a hiatus. The succeeding three assemblages have 
gradual transitions independent of lithological changes. No significant hiati have been observed in this part of the sequence in the Schuchert Dal region.

\section{Potonieisporites assemblage}

The assemblage is completely dominated by monosaccate Pollenites especially the genus Potonieisporites and possibly some Florinites. The genus Cheiledonites occurs but is less common and there are only very few specimens of nonstriate Disaccites and Triletes. Single specimens of striate Disaccites have been recorded but the genus Vittatina appears to be absent. Triletes becomes more frequent in the lowermost part of the assemblage in Skeldal (fig. 1).

The age of the Potonieisporites assemblage is interpreted to be mainly earliest Permian (Autunian) by comparison with zone $\mathrm{A} 2$ of Doubinger (1974) and with the Vittatina costabilis Zone of Clayton et al.(1977). The assemblage is believed to represent a very short time-interval close to the Carboniferous - Permian boundary, as representatives of the genus Vittatina have not yet appeared. The slight increase in density and diversity of Triletes in the lower part of the assemblage suggests that this part of the assemblage may be of Late Carboniferous age.

Occurrence: The Potonieisporites assemblage occurs in all productive samples from the Mesters Vig Formation (fig. 2). The assemblage occurs in the Skeldal, Blyklippen and Profilbjerget Members of Mesters Vig Formation in Scoresby Land. The overlying Domkirken Member consists of sandstone and conglomerate and is lacking finegrained sediments which could provide palynomorphs. The coarse-grained and geographically restricted Aggersborg Member has not been sampled.

The occurrence of the Potonieisporites assemblage in the Gurreholm Dal Formation is only known from the Snekuppel Member on both sides of Schuchert Dal. All samples from the Arkosedal and Ødemarksdal Members are barren. The palynomorphs have probably degraded due to primary oxygenation in the alluvial fan environments in contrast to their occurrence in the fluviatile environments of the Snekuppel Member. Kempter (1961) reports a palynological dating of one bed at the boundary of Ødemarksdal and Arkosedal Members to an Early Permian age. This corresponds to the age of the Potonieisporites assemblage. The Konglomeratpas Member has not been sampled.

On the basis of the abundant occurrence of small fossil fishes in the thin black shale or carbonate beds of the Skeldal, Blyklippen, Profilbjerget and Snekuppel Members, it has been argued that these beds resulted from marine transgressions (Bierther 1941, Witzig 1954). There is no palynological indication of marine influence in any part of the Lower Permian sediments and this is in accordance with the later interpretation of the fishes as fresh water acanthodians and palaeonisciforms (Jensen 1975, Bendix-Almgreen 1976).

\section{Vittatina assemblage}

The assemblage is totally dominated by species of the genus Vittatina. The only other relatively abundant forms are striate Disaccites. A few centimetre thick beds containing concentrations of Tasmanites occur.

The assemblage is identical to the Vittatina assemblage from Kap Stosch (Balme 1979). A difference is the complete absence of acritarchs which are abundant at Kap Stosch.

On the basis of correlation to the material from Kap Stosch (Balme 1979) the assemblage is interpreted to be of Late Permian age. In a comprehensive review Hart (1970) points out that in the classical Russian platform region of the Euramerican Flora Province, the genus Vittatina reaches significant maximum abundance in the Kungurian Stage (Zauer 1960, 1964 in Hart 1970). If the Vittatina assemblage of Jameson Land correlates with this maximum then the age is latest Early to Late Permian.

Occurrence: The Vittatina assemblage is restricted to the lower part of the Foldvik Creek Formation. No palynomorphs' have been recorded from the basal conglomerate but the assemblage occurs in shaly beds within carbonates and gypsum. The bituminous "Posidonia Shale" contains a high proportion of organic material including the Vittatina assemblage and the upper boundary of the assemblage is coincident with a drastic fall in content of organic matter. 
The Vittatina assemblage occurs in the Schuchert Dal region. The organic material in the equivalent sediments in other regions is highly mature and palynomorphs are completely degraded.

\section{Protohaploxypinus assemblage}

The Protohaploxypinus assemblage is completely dominated by striate Disaccites. The genus Protohaploxypinus is frequent throughout the interval but the genus Vittatina is abundant in the lower part becoming gradually replaced by Taeniaesporites in the upper part. Striatoabieites is common and trilete Disaccites is present but rare. Trilete spores and acritarchs are more abundant than in the assemblages below and above but they form only a small fraction of the assemblage. The abundant macro-fauna in both Foldvik Creek and Wordie Creek Formations indicate marine conditions. This is in contrast to the general absence of acritarchs and other marine palynomorphs in the three assemblages.

It is expected that this assemblage may be subdivided further when more detailed investigations have been carried out.

The assemblage is similar but not identical to the Protohaploxypinus assemblage from Kap Stosch (Balme 1979). The exact age of the assemblage is uncertain. Compared to the description of the stratigraphic evolution of the palynofloras of Russia (Hart 1970) a Late Permian (Kazanian - Tatarian) age is probable. However, the similar assemblage described by Balme (1979) from Kap Stosch is dated as lowermost Triassic on the basis of ammonites and conodonts. An accurate dating must await further studies.

Occurrence: The Protohaploxypinus assemblage occurs in the lithologically variable upper part of the Foldvik Creek Formation. The assemblage is preliminarily recorded in the Schuchert Dal region and at Domkirken in Scoresby Land. The sequence at Wegener Halvø is thermally degraded.

\section{Taeniaesporites assemblage}

The assemblage is recorded from a small number of samples, but from many localities. The organic material in these samples is in general of high thermal maturation. Thus pollen and spores are severely damaged and morphological characteristics are difficult to study, but the genus Taeniaesporites is determinable and is abundant. Disaccites is the main constituent of the assemblage but better preserved material is necessary before specific determination is possible.

The age of the assemblage is Early Triassic as it occurs in the Wordie Creek Formation where a detailed Lower Triassic ammonite stratigraphy has been established (Grasmück \& Trümpy 1969). The assemblage may be correlated with the Taeniaesporites assemblage reported by from Lower Triassic sediments at Kap Stosch (Balme 1979).

Occurrence: The Taeniaesporites assemblage always occurs in the lower part of the Wordie Creek Formation. It is recorded at several localities in the Schuchert Dal region, in Wegener Halvø and in Domkirken, Scoresby Land.

\section{Conclusion}

Four pollen and spore assemblages have been recognised in the Permian-Lower Triassic sequence of Jameson Land and Scoresby Land. From below they comprise the Potonieisporites, the Vittatina, the Protohaploxypinus and the Taeniaesporites assemblages. These assemblages will be of great value in dating material acquired from deep wells. The assemblages appear sufficiently diverse to provide the basis for a more detailed zonation.

These preliminary results indicate that the Gurreholm Dal and the Mestersvig Formations comprises Lower Permian sediments and only the lower part of the Skeldal Member may be of Late Carboniferous age. The Foldvik Creek Formation is mainly Upper Permian but the Protohaploxypinus assemblage from the upper part of the formation is probably of Early Triassic age. The Wordie Creek Formation is of Early Triassic age.

The Potonieisporites assemblage shows affinity to the NW-European microfloras. On the other hand, the Vittatina, Protohaploxypinus and Taeniaesporites assemblages differ significantly from microfloras of the NW-European Zechstein Buntsandstein (Klaus 1963, Clarke 1965, Visscher 1971). They are, however, comparable to 
the assemblages from Kap Stosch $250 \mathrm{~km}$ to the north of Jameson Land (Balme 1979) and to the microfloras from the Permian type region of the Russian platform (Hart 1970).

Acknowledgements. F. Surlyk and J. M. Hurst are thanked for critical reading of the manuscript and for constructive suggestions. K. Villadsen, N. Turner and B. Sikker-Hansen are thanked for careful preparation of the samples and the manuscript. The paper is published with permission of the Director of the Geological Survey of Greenland.

\section{Dansk sammendrag}

De Perme - Nedre Triassiske sedimenter i Jameson Land Scoresby Land (fig. 1) er biostratigrafisk / palynologisk undersøgt, og der er fundet fire veldefinerede palyno-floraer baseret på pollen og sporer. Disse palyno-floraer daterer lagserien og vil vare stratigrafisk anvendelige ved eventuelle dybe boringer $i$ området.

I Gurreholm Dal og Mesters Vig Formationerne (fig. 2) er der fundet en Potonieisporites flora, som er helt domineret af monosaccate pollen. Ved sammenligning med Europæiske Permo-Karbone palyno-floraer kan de to formationer dateres til Autunien, nederste Perm. Kun i den nederste del af Mesters Vig Formationen i Skeldal er der et højere indhold at trilete sporer, som måske antyder en Karbon alder.

I Foldvik Creek og Wordie Creek Formationerne er der fundet tre palyno-floraer, som kan sammenlignes med de tre tilsvarende floraer beskrevet fra Kap Stosch $250 \mathrm{~km}$ nordligere af Balme (1979). Den nederste del af Foldvik Creek Formationen indeholder en flora domineret af slagten Vittatina med gradvis overgang til en Protohaploxypinus domineret flora i den gvre del af formationen. Der er ligeledes gradvis overgang til en Taeniaesporites domineret flora i den nederste del af Wordie Creek Formationen.

Ved sammenligning med beskrivelserne fra Kap Stosch og fra Perm type-området i Rusland kan Vittatina floraen dateres til $\emptyset$ vre Perm og Taeniaesporites floraen til Nedre Trias. Den mellemliggende Protohaploxypinus flora kan endnu ikke date-

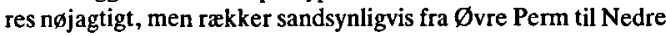
Trias i alder. Denne flora forventes at kunne opdeles yderligere senere.

\section{References}

Balme, B. E., 1979: Palynology of Permian-Triassic boundary beds at Kap Stosch, East Greenland. Meddr Grønland 200 (6), $37 \mathrm{pp}$.

Bendix-Almgreen, S. E., 1976: The palaeovertebrate faunas of Greenland. In: Escher, A. \& Watt, W. S. (eds.) Geology of Greenland, 537-573.

Bierther, W., 1941: Vorlaüfige mitteilung über die geologie des östlichen Scoresbylandes in Nordostgrönland. Meddr Grønland 114 (6), $20 \mathrm{pp}$

Bütler, H. 1961: Continental Carboniferous and Lower Permian in central East Greenland. In Raasch, G. O. (ed.) Geology of the Arctic 1, 205-213.

Clarke, R. F. A., 1965: British Permian saccate and monosulcate miospores. Palaeontology 8, 322-354.

Clayton, G., Coquel, R., Doubinger, J. Gueinn, K. J., Loboziak, S., Owens, B. \& Streel, M. 1977: Carboniferous miospores of Western Europe: Illustration and zonation. Meded. Rijks Geol. Dienst 29, 1-71.

Collinson, J. D. 1972: The Røde $\emptyset$ conglomerate of inner Scoresby Sund and the Carboniferous (?) and Permian rocks west of the Schuchert Flod. A general sedimentological account. Meddr Gronland 192 (6), 48 pp.

Doubinger, J., 1974: Etudes palynologique dans L'Autunien. Rev. Palaeobot. Palynol. 17, 21-38.

Grasmück, K. \& Trümpy, R., 1969: Triassic stratigraphy and general geology of the country around Flemming Fjord (East Greenland). Meddr Grønland 168 (2), 5-71.

Halle, T. G., 1931: Younger Palaeozoic plants from East Greenland collected by the Danish expeditions 1929 and 1930. Meddr Grønland 85 (1), 26 pp.

Hart, G. F., 1970: The biostratigraphy of Permian palynofloras. Geoscience and Man 1, 89-131.

Jensen, S. R., 1975: Acanthodians from the Permo-Carboniferous boundary in Central East Greenland. Colloque international C.N.R.S. 218, 125-135.

Kempter, E., 1961: Die Jungpaläozoischen sedimente von süd Scoresby Land (Ostgrönland, 71 1/2 N). Meddr Grønland 164 (1), $124 \mathrm{pp}$.

Klaus, W., 1963: Sporen aus dem südalpinen Perm. Jb. Geol. B. A. 106, 229-361

Koch, L., 1929: The geology of East Greenland. Meddr Grønland 73 (2), 1-134.

Perch-Nielsen, K., Bromley, R. G., Birkenmajer, K. \& Aellen, M., 1972: Field observations in Palaeozoic and Mesozoic sediments of Scoresby Land and Northern Jameson Land. Rapp. Grønlands geol. Unders. 48, 39-59.

Visscher, H., 1966: Palaeobotany of the Mesophytic III. Plant microfossils from the Upper Bunter of Hengelo, the Netherlands. Acta Botanica Neerlandica 15, 316-375.

Visscher, H., 1971: The Permian and Triassic of the Kingscourt Outlier, Ireland. Geol. Surv. Irl., Spec. pap. 1, 114 pp.

Witzig, E. 1951: Einige jungpaläozoische pflanzen aus Ostgrönland. Meddr Gronland 114 (11), $35 \mathrm{pp}$.

Witzig, E. 1954: Stratigraphische und tektonische Beobachtungen in der Mesters Vig-Region (Scoresby Land, Nordostgrönland). Meddr Grønland 72, 2 (5), 26 pp. 